Canadian

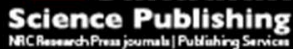

Applied Physiology, Nutrition, and Metabolism Physiologie appliquée, nutrition et métabolisme

\title{
Histamine H2 Receptor Blockade Augments Blood Pressure Responses to Acute Submaximal Exercise in Males
}

\begin{tabular}{|r|l|}
\hline Journal: & Applied Physiology, Nutrition, and Metabolism \\
\hline Manuscript ID & apnm-2015-0450.R3 \\
\hline Manuscript Type: & Article \\
\hline Date Submitted by the Author: & 22-Dec-2015 \\
\hline Complete List of Authors: & $\begin{array}{l}\text { Doh, Hyung-Woo; Kyung Hee university, Graduate School of Physical } \\
\text { Education } \\
\text { Stebbins, Charles; University of California, Davis, Internal Medicine } \\
\text { Choi, Hyun-Min; Kyung Hee university, Graduate School of Physical } \\
\text { Education } \\
\text { Park, Joonsung; Kyung Hee university, Graduate School of Physical } \\
\text { Education } \\
\text { Nho, Hosung; Kyung Hee university, Graduate School of Physical Education } \\
\text { Kim, Jong-Kyung; Kyung Hee university, Graduate School of Physical } \\
\text { Education }\end{array}$ \\
\hline Keyword: & \begin{tabular}{l} 
cycling, norepinephrine, rate x pressure product, stroke volume, ranitidine \\
\hline
\end{tabular} \\
\hline
\end{tabular}

\section{SCHOLARONE"}

Manuscripts 
Histamine $\mathrm{H}_{2}$ Receptor Blockade Augments Blood Pressure Responses to Acute Submaximal Exercise in Males

Hyung-Woo Doh ${ }^{1}$, Charles L. Stebbins ${ }^{2}$, Hyun-Min Choi ${ }^{1}$, Joonsung Park ${ }^{1}$, Hosung $\mathrm{Nho}^{1}$, and Jong-Kyung Kim ${ }^{1}$

${ }^{1}$ Graduate School of Physical Education

Kyung Hee University

Yongin, Korea

and

${ }^{2}$ Department of Internal Medicine

Division of Cardiovascular Medicine

University of California

Davis, CA, USA

Direct Correspondence to:

Jong-Kyung Kim, Ph.D.

1 Seocheon-dong Giheung-gu

Yongin-si Gyeonggi-do, Korea 446-701

Phone: 8231) 201-2778

Fax: 8231) 201-3743

Email: kyung19692002@khu.ac.kr 


\begin{abstract}
Histamine is a potent vasodilator that has been found to increase during exercise. We tested the hypothesis that histamine attenuates blood pressure, cardiac output (CO) and vascular resistance responses to short term, submaximal dynamic exercise during $\mathrm{H}_{2}$ receptor blockade. Fourteen healthy men (20-29 yr) were studied. Systolic (SBP), diastolic (DBP) and mean (MAP) arterial blood pressure and heart rate (HR) were assessed at rest and during the last min of 10 min of submaximal cycling exercise $\left(60 \%\right.$ of $\left.\mathrm{V0}_{2 \text { peak }}\right)$ in the absence and presence of histamine $\mathrm{H}_{2}$ receptor blockade (ranitidine, 300 $\mathrm{mg}$ ). Stroke volume (SV) (impedance cardiography) and plasma norepinephrine (NE) were measured and $\mathrm{CO}$, rate $\mathrm{x}$ pressure product (RPP) and total peripheral resistance (TPR) were calculated. Plasma levels of histamine were also measured. $\mathrm{H}_{2}$ blockade had no effects on any variables at rest. During exercise, SBP ( $184 \pm 3$ vs. $166 \pm 2 \mathrm{mmHg})$, MAP (121 \pm 2 vs. $112 \pm 5 \mathrm{mmHg})$, RPP $\left(25.9 \pm 0.8 \times 10^{3}\right.$ vs. $23.5 \pm 0.8 .0 \times 10^{3}$ $\mathrm{mmHg} \bullet$ beats $/ \mathrm{min})$ were greater during blocked conditions $(\mathrm{P}<0.05)$ and an interaction was observed for TPR. SV, DBP, HR and NE levels were unaffected by blockade. Plasma histamine increased from 1.83 $\pm 0.14 \mathrm{ng} / \mathrm{ml}$ at rest to $2.33 \pm 0.23 \mathrm{ng} / \mathrm{ml}$ during exercise $(\mathrm{P}<0.05)$ and was not affected by $\mathrm{H}_{2}$ blockade $(1.56 \pm 0.23$ vs. $1.70 \pm 0.24 \mathrm{ng} / \mathrm{ml})$. These findings suggest that, during submaximal exercise, histamine attenuates blood pressure, vascular resistance and work of the heart via activation of $\mathrm{H}_{2}$ receptors, and that these effects primarily occurred in the vasculature and not in the myocardium.
\end{abstract}

Keywords: cycling; norepinephrine; rate x pressure product; stroke volume; ranitidine 


\section{Introduction}

A major cardiovascular effect of histamine in humans is peripheral vasodilation (Skidgel et al. 2012). Since histamine increases during short term dynamic exercise (Campos et al. 1999) and has been shown to play a role in mediating post-exercise hypotension (Lockwood et al. 2005; McCord et al. 2006), it may also contribute to hyperemic and blood pressure responses to exercise. Presumably, potential effects could be mediated, at least in part, via stimulation of peripheral $\mathrm{H}_{2}$ receptors as they are instrumental in mediating histamine-induced vascular responses (Hill, 1990; Brown and Roberts 2001) that include reductions in blood pressure and vascular resistance (Black et al. 1975).

Results of previous studies using $\mathrm{H}_{2}$ antagonists reported no effects on blood pressure or heart rate during exercise (Saltissi et al. 1981; Hughes et al. 1989; McCord et al. 2006). However, it is worth considering that possible cardiovascular effects of histamine might have been mitigated by the nature of the exercise protocols used in these studies. For example, blood pressure responses were assessed by McCord et al. (2006) at the end of a prolonged exercise test and by Saltissi et al. (1981) during at maximal exercise. It may be that the ability of histamine $\mathrm{H}_{2}$ receptors to mediate cardiovascular responses during exercise depends, in part, on work intensity and/or duration. Thus, short term, submaximal dynamic exercise may represent more optimal conditions for detecting potential effects.

The duration of $\mathrm{H}_{2}$ blockade may represent another intervening factor. While Saltissi et al. (1981) and Hughes et al. (1989) conducted chronic $\mathrm{H}_{2}$ receptor blockade, effects of acute blockade on the cardiovascular response to short bouts of submaximal dynamic exercise have not been examined.

Guided by these considerations, we tested the hypothesis that histamine augments blood pressure, cardiac output and vascular resistance responses to short term, submaximal dynamic exercise during $\mathrm{H}_{2}$ receptor blockade. 


\section{Methods}

A total of 14 male volunteers, aged 20-29 years, participated in this study. Male subjects were selected to avoid potential effects of the menstrual cycle on exercise hemodynamics (Choi et al. 2013). They were recruited from the Kyung Hee University campus and surrounding community. All subjects were considered to be in good health and had not performed regular physical activity for at least 6 months before the start of the study. They were also nonsmokers and were not taking medications that could affect cardiovascular function. Prior to any intervention, subjects were instructed to abstain from alcohol, caffeine, and strenuous exercise for $24 \mathrm{~h}$. All procedures and protocols used in this study were reviewed and approved by the Kyung Hee University Human Investigation Committee. The potential risks and benefits of the protocol were explained to each subject before they provided written informed consent.

\section{Experimental procedures}

After reporting to the laboratory and resting quietly for $30 \mathrm{~min}$, blood pressure (BP) was assessed at rest with each subject in the sitting position. Three BP measurements (using an appropriately sized pressure cuff) were obtained 5 min apart using a mercury sphygmomanometer with the cuff positioned on the left arm at the level of the heart while the subject was seated with his back supported in a chair and both feet on the floor. Blood pressure was expressed as the average of the 3 measurements. To determine the relative exercise intensity for the study, subjects completed a $\mathrm{VO}_{2 \text { peak }}$ test on a braked cycle ergometer (Monark 828, Sweden) using an Ultima CPX metabolic measurement cart (Medgraphic, USA). All subjects cycled at 0 watts for $2 \mathrm{~min}$. Subsequently, the work rate was increased progressively by 30 watts every min until exhaustion was reached. The $\mathrm{VO}_{2 \text { peak }}$ obtained from this test was then used to calculate the respective work intensities for each subject.

\section{Exercise protocol}


Every subject performed a 12 min bout of cycling exercise in the absence and presence of histamine $\mathrm{H}_{2}$ receptor blockade. The exercise paradigm employed a pedal frequency of $60 \mathrm{rpm}$. Two min of exercise were performed at 0 watts followed by $5 \mathrm{~min}$ at $40 \% \mathrm{VO}_{2 \text { peak }}$ and ending with an additional 5 $\min$ at $60 \% \mathrm{VO}_{2 \text { peak. }}$. Since our subjects were sedentary, we designed this progressive submaximal exercise test to optimize the ability of the subjects to reach and maintain a steady state prior to assessment of the hemodynamic variables. The same absolute workload was performed in both conditions. Data were collected continuously throughout the experiment. All hemodynamic data were obtained at rest (while sitting at rest on the cycle) and during exercise. All measurements during exercise were made during the last 1-1.5 min of the $60 \% \mathrm{VO}_{2 \text { peak }}$ work intensity. The two exercise tests were separated by at least one week. The order of treatment (control vs. $\mathrm{H}_{2}$ blockade) was randomized among subjects. All tests were performed at the same time of day for each subject (i.e., in the morning).

Histamine $\mathrm{H}_{2}$ blockade was induced by ranitidine HCL $300 \mathrm{mg}$ (brand name: Zantac; Pfizer Consumer Healthcare, Morris Plains, NJ). Subjects ingested ranitidine $2.5 \mathrm{~h}$ before the onset of each protocol because this dose of oral ranitidine reaches its peak concentration at $2.2 \mathrm{~h}$ (with a $2.6 \mathrm{~h}$ half-life) and blocks $\mathrm{H}_{2}$ receptors. On experiment days, subjects were given water with or without the study drug. Ranitidine was selected because it does not cross the blood brain barrier, evoke direct cardiovascular effects or induce sedation (Brown and Roberts, 2001). Its mechanism of action involves reductions in smooth muscle intracellular calcium levels that are induced via the binding of histamine; an effect that can last for up to $6 \mathrm{~h}$ (Garg et al. 1985; Hill, 1990; Brown and Roberts. 2001).

\section{Measurement of hemodynamic variables}

Non-invasive measures of stroke volume (SV) were obtained via impedance cardiography (Physio Flow, Manatec Biomedical, France) at rest and during exercise. This technique assesses changes in impedance in the thorax that can be used to obtain values of SV (Charloux et al. 2000; Richard et al. 2001; Tordi et al. 2004). In brief, it involves transmission of a high-frequency, low magnitude AC current via two sets of skin electrodes (one set placed above the base of the neck, the other placed on the 
thorax along the mid-axillary line at the level of the xiphoid process). Subsequently, variations in impedance associated with the flow of current across the thorax during the cardiac cycle are used to calculate SV.

Cardiac output (CO) is then calculated as HR x SVi x BSA, where SVi is the SV index (i.e., $\mathrm{SV} / \mathrm{BSA}$ ) and BSA is body surface area in meters squared $\left(\mathrm{m}^{2}\right)$. BSA was calculated as $0.024265 \mathrm{x}$ $\mathrm{BM}^{0.5378} \mathrm{x} \mathrm{H}^{0.3964}$, where $\mathrm{BM}$ is body mass in kilograms and $\mathrm{H}$ is height in centimeters. HR was measured by ECG using the R-R interval.

The Physioflow technique has been validated against the direct Fick method for assessment of SV and $\mathrm{CO}$ at rest and during exercise (Charloux et al. 2000).

Brachial artery pressure was obtained from the left arm using sphygmomanometery during steady state exercise. Mean arterial blood pressure (MAP) was calculated from systolic blood pressure (SBP) and diastolic blood pressure $(\mathrm{SBP})$ according to the formula: $\mathrm{MAP}=[(\mathrm{SBP}-\mathrm{DBP}) \div 3)+\mathrm{DBP}$. Total peripheral resistance $(\mathrm{TPR})$ was calculated as $\mathrm{MAP} \div \mathrm{CO}$ and rate $\mathrm{x}$ pressure product $(\mathrm{RPP})$, an index of the work of the heart, as HR x SBP. All blood pressure measurements in a given subject were made by the same investigator.

\section{Biochemical analyses}

Histamine concentrations at rest and during exercise in the absence and presence of $\mathrm{H}_{2}$ receptor blockade were assessed to determine if our selected work intensity was capable of evoking the release of this amine. Blood samples were collected via an intravenous catheter at rest and at each workload during steady-state conditions. Blood samples were collected into pre-chilled tubes containing EDTA, centrifuged at $3000 \mathrm{rpm}$ and stored at $-80^{\circ} \mathrm{C}$. Histamine concentrations were determined using an enzyme immunoassay kit (Labor Diagnostika Nord GmbH \& Co. KG, Germany). The intra-assay coefficient of variation for histamine was $6.0 \%$. 
Norepinephrine (NE) concentrations were assessed as an overall index of sympathetic nerve activity and to determine any possible effects of $\mathrm{H}_{2}$ receptor blockade on NE release. They were determined by reverse phase high-performance liquid chromatography (HPLC). Extraction of NE was performed by selective absorption from aluminum oxide (Plasma-Catecholamine-Kit, BIO-RAD, Korea). A $200 \mu \mathrm{L}$ internal standard solution $+1 \mathrm{ml}$ Tris Buffer was added. The suspension was shaken for 12 min followed by centrifugation at $2500 \mathrm{rpm}$ for $5 \mathrm{~min}$. Subsequently, the supernatant (minus the alumina) was aspirated using a vacuum aspirator. The samples were then centrifuged again at $2500 \mathrm{rpm}$ for $2 \mathrm{~min}$.

Chromatographic analysis of NE was conducted using a HPLC system (Agilent, model 1260, Santa Clara, USA), which consisted of an autosampler and quaternary pump coupled to an ESA Coulochem II coulometric detector (Thermo Fisher Scientific Inc., Waltham, USA). Column effluent was monitored with an electrochemical detector that was equipped with a 5011 high sensitivity dual electrode analytical cell (electrodes 1 and 2) for assessment of oxidation of the analytes (electrode 1: $-300 \mathrm{mV}, 10$ $\mu \mathrm{A}$; electrode 2: $450 \mathrm{mV}, 50 \mathrm{nA}$ ). The mobile phase consisted of $50 \mathrm{~mL}$ in $125 \mathrm{mmol} / \mathrm{L}$ diammonium hydrogen orthophosphate containing $0.1 \mathrm{~g}$ of heptane sulphonic acid (Sigma Chemical Co, St. Louis, USA) and $0.073 \mathrm{~g}$ of EDTA (Sigma-Aldrich) in $1 \mathrm{~L}$ water adjusted to a pH of 3.5. An Agilent Poroshell $120 \mathrm{C} 18-\mathrm{EC} 2.7 \mu \mathrm{m}$ analytical column (150 x $3.0 \mathrm{~mm}$ id) (Agilent Technologies, Berkshire, UK) was used with a flow rate of $1.0 \mathrm{~mL} / \mathrm{min}$. Fifty $\mu \mathrm{L}$ of the sample was injected into the HPLC injector. The intra-assay coefficient of variation was $4.0 \%$.

\section{Data analysis}

SV measurements using impedance cardiography (i.e., averaging procedures in steady-state conditions) have been shown to be reliable and valid in healthy subjects (Charloux et al. 2000; Richard et al. 2001; Kaplan et al. 2003; Tordi et al. 2004) . Accordingly, this device accurately evaluates the 
absolute values of SV at rest and during dynamic exercise. Absolute changes in HR, SV, CO, MAP, and TPR are expressed as means $\pm \mathrm{SE}$

Thirty s averages of all variables were taken at rest and during the last 1-1.5 min of exercise at the $60 \% \mathrm{VO}_{2 \text { peak }}$ workload and compared between unblocked and blocked conditions. Hemodynamic variables and plasma concentrations of NE and histamine were analyzed using a two-way ANOVA with repeated measures for comparison with respect to treatment (control vs. ranitidine) x condition (rest vs. during exercise). If a significant interaction was found, post hoc tests were performed via Tukey's test. The criterion for significant differences was $P<0.05$. 


\section{Results}

Physical characteristics of subjects are presented in Table 1.

Figure 1 shows mean values of SBP, DBP, MAP and HR at rest and during exercise in the absence (control) and presence of $\mathrm{H}_{2}$ receptor blockade. A significant effect (treatment x condition) was found for both SBP $(184 \pm 3$ vs. $166 \pm 2 \mathrm{mmHg})$ and MAP $(121 \pm 2$ vs. $112 \pm 2 \mathrm{mmHg})(P<0.05)$. During Exercise SBP and MAP increased in both conditions, while blockade resulted in a further increases compared to control conditions $(\mathrm{P}<0.05)$. Although no interaction was observed for DBP, treatment and condition effects were found $(\mathrm{P}<0.05)$. A condition effect was also found for $\mathrm{HR}(P<0.05)$. Exercise caused increases in DBP and HR from rest in both conditions $(\mathrm{P}<0.05)$.

Figure 2 depicts mean values of CO, SV, TPR and RPP at rest and during exercise in the absence and presence of $\mathrm{H}_{2}$ blockade. A treatment x condition effect was seen for RPP ( $25.9 \pm 0.8 \times 10^{3}$ vs. $23.5 \pm$ $0.8 \times 10^{3} \mathrm{mmHg} \cdot$ beats $\left./ \mathrm{min}\right)(P<0.05)$. Exercise increased RPP from rest in both conditions and this increase was attenuated during receptor blockade. Both treatment and condition effects were also revealed for TPR. This variable was reduced during exercise in both conditions. During blockade, TPR was higher at rest and during exercise compared to control values. Only condition effects were found for SV and $\mathrm{CO}$ as both parameters increased from rest to exercise in control and blocked conditions. Mean values for SV were: control rest, $61 \pm 2 \mathrm{ml}$, control exercise, $80 \pm 2 \mathrm{ml}$, blockade rest, $62 \pm 2$ and blockade exercise, $82 \pm 2 \mathrm{ml}$. For CO, means were: control rest: $4.5 \pm 0.1 \mathrm{~L} / \mathrm{min}$, control exercise, $11.3 \pm 0.3 \mathrm{~L} / \mathrm{min}$, blockade rest, $4.5 \pm 0.1 \mathrm{~L} / \mathrm{min}$ and blockade exercise, $11.4 \pm 0.3 \mathrm{~L} / \mathrm{min}$.

As presented in Figure 3, we found a condition effect on plasma concentrations of $\mathrm{NE}(P<0.05)$ as they increased from rest to exercise in both treatments $(\mathrm{P}<0.05)$.

A condition effect on plasma concentrations of histamine was observed as they increased from $1.83 \pm 0.14 \mathrm{ng} / \mathrm{ml}$ at rest to $2.33 \pm 0.23 \mathrm{ng} / \mathrm{ml}$ during exercise in unblocked conditions and from $1.56 \pm$ 
0.23 to $1.70 \pm 0.24 \mathrm{ng} / \mathrm{ml}$ during $\mathrm{H}_{2}$ blockade $(\mathrm{P}<0.05)$. On the other hand, no treatment effect of $\mathrm{H}_{2}$ blockade was found at rest or during exercise. 


\section{Discussion}

Results of this study confirm our hypothesis that during submaximal dynamic exercise, histamine can attenuate blood pressure and vascular resistance responses via activation of peripheral $\mathrm{H}_{2}$ receptors. In this regard, blockade of these receptors enhanced exercise-induced increases in MAP, SBP and RPP and attenuated concomitant reductions in TPR (which is indicative of vasoconstriction) without altering concomitant increases in plasma histamine. Thus, it appears that histamine contributes to the cardiovascular response to acute submaximal exercise by causing peripheral vasodilation and reducing the afterload on the heart. If so, it seems reasonable to expect that these outcomes would lead to increases in peripheral blood flow as well as reduction in cardiac workload at a given work intensity.

In spite of the higher levels of MAP and TPR mediated by $\mathrm{H}_{2}$ receptor blockade, no changes in $\mathrm{CO}$ or SV were seen. Logically, an increase in these two variables would be expected to reduce both $\mathrm{CO}$ and peripheral blood flow. However, according to the basic flow equation, where $\mathrm{CO}=\mathrm{MAP} \div \mathrm{TPR}, \mathrm{CO}$ would remain constant if the magnitude of the increase in TPR is offset by an increase in perfusion pressure (MAP) of equal magnitude. Another possibility is that $\mathrm{H}_{2}$ inhibition caused a redistribution of $\mathrm{CO}$ such that reductions in blood flow in some regional circulation were offset by increases in others. In this regard, a study in cats found that infusion of an $\mathrm{H}_{2}$ receptor agonist (4-methylhistamine) lowered MAP and decreased TPR but had no effect on CO or SV. These responses were accompanied by increases in blood flow to the heart, stomach and small and large intestines and reductions in flow to the kidneys, skin, liver and spleen (Johnson and Owen, 1977).

Histamine, via stimulation of $\mathrm{H}_{2}$ receptors, can cause increases in myocardial contractility in humans (Watkins et al. 1982). Since we did not assess inotropic state in our subjects, we cannot draw any conclusions concerning the role of these receptors in exercise-induced increases in contractility. We can only speculate that any effects of $\mathrm{H}_{2}$ receptor-evoked increases in myocardial contractility during exercise were likely minimal, as SV and $\mathrm{CO}$ were not altered by treatment with ranitidine. These outcomes 
suggest that effects of $\mathrm{H}_{2}$ receptor activation on the cardiovascular response to exercise are likely to be peripheral in nature (i.e., in the vasculature).

Our findings are in contrast to those reported in previous studies (Saltissi et al. 1981; Hughes et al.1989). In one of these studies (Hughes et al. 1981), the $\mathrm{H}_{2}$ receptor antagonists cimetidine and ranitidine had no effects on SBP, DBP or HR compared to unblocked conditions in response to progressive increases in work intensity during treadmill running. In the other, $\mathrm{H}_{2}$ blockade with cimetidine had no effects on SBP or HR in response to maximal exercise (Saltissi et al. 1981). However, there were differences between these protocols and ours that may account for these differential findings. As mentioned previously, the $\mathrm{H}_{2}$ antagonists were administrated chronically (i.e., over a 7 or 28 day period) compared to a single acute dose used in the present study. This is an important distinction because chronic administration of the $\mathrm{H}_{2}$ inhibitors may have led to the development of a tolerance to potential cardiovascular effects caused by these drugs.

Another issue may be the duration of exercise. McCord et al. (2006), using a dose of ranitidine similar to ours, found no effects of $\mathrm{H}_{2}$ receptor blockade on the blood pressure response to 60 min of submaximal exercise. Interestingly, they also reported no effects of this exercise protocol on blood or plasma concentrations of histamine (McCord et al. 2006). In contrast, exercise of shorter duration (i.e., 6$12 \mathrm{~min}$ ) has been shown to induce increases in blood histamine levels (Campos et al. 1999). Thus, it is possible that production of histamine during exercise wanes over time. The reason for this apparent differential effect is not clear. One possibility is that prolonged sympathetic activity may have an inhibitory effect on histamine production, as withdrawal of sympathetic activity has been associated with release of this amine (Brody, 1966; Powell and Brody, 1976; Rengo et al. 1976).

Although believed to be primarily facilitated by $\mathrm{H}_{3}$ receptors (Malinowska et al. 1998), there are some data provided by older studies indicating that histamine can cause peripheral vasodilation via a nonneural inhibitory action on noradrenergic nerve transmission, and that this effect is mediated by activation 
of histamine $\mathrm{H}_{2}$ receptors (McGrath and Shepherd, 1978). The $\mathrm{H}_{2}$ receptors in question are located on the nerve endings of postganglionic sympathetic nerves (Langer and Arbilla, 1990). When stimulated, these receptors can act prejunctionally to attenuate the release of norepinephrine; possibly by interfering with exocytosis (McGrath and Shepherd, 1978; Shepherd and Vanhoutte, 1985). This outcome raises the possibility that the enhanced pressor response to exercise during $\mathrm{H}_{2}$ receptor blockade seen in our subjects was due, at least in part, to a reduction in histamine-evoked inhibition of sympathetic-induced increases in norepinephrine release in the periphery; an effect that could have led to increases in TPR and, in turn, blood pressure. However, we feel that this scenario was unlikely because plasma concentrations of norepinephrine at rest and during exercise in our study were unaffected by $\mathrm{H}_{2}$ receptor blockade.

It is conceivable that at least a portion of the enhanced blood pressure response to exercise during $\mathrm{H}_{2}$ receptor blockade was due to alterations in baroreflex function. The dose of ranitidine used in our study has previously been shown to decrease baroreflex sensitivity and alter cardiac sympathovagal balance; suggesting a shift towards predominance of sympathetic control of heart rate (Nault et al. 2002). While we cannot dismiss this possibility, the functional relevance of such an effect appears to be limited as heart rate and norepinephrine concentrations at rest and during exercise were not different between control and $\mathrm{H}_{2}$ blockade conditions.

Although effects of histamine $\mathrm{H}_{1}$ receptor blockade were not assessed in the present study, we cannot dismiss a possible contribution of these receptors to effects of histamine on the cardiovascular response to dynamic exercise. That is because activation of $\mathrm{H}_{1}$ receptors located on vascular endothelial cells is capable of causing vasodilation indirectly by inducing the release of substances such as nitric oxide and prostaglandins; substances that have been shown to play a role in the regulation of skeletal muscle blood flow during exercise (Schrage et al. 2004). Although a previous study using the $\mathrm{H}_{1}$ receptor antagonist chlorpheniramine maleate found no effects of $\mathrm{H}_{1}$ receptor inhibition on MAP or TPR during 20 min of submaximal exercise (Peterlin et al, 1998), only a single over-the-counter dose of this antagonist 
was used (4 mg). Thus, it is possible that a higher dose of this drug may have been necessary to induce effective $\mathrm{H}_{1}$ receptor blockade.

On the other hand, histamine has been shown to enhance the discharge of group III and IV muscle afferents that mediate the exercise pressor response (Kumazawa and Mizumura, 1979; Mitchell et al. 1983) and to cause reflex-induced increases in blood pressure via stimulation of $\mathrm{H}_{1}$ but not $\mathrm{H}_{2}$ receptors located on the nerve endings of similar afferents in the wall of the stomach (i.e., $\mathrm{C}$ and $\mathrm{A} \delta$ fibers); an effect that can be attenuated in response to $\mathrm{H}_{1}$ receptor blockade (Stebbins et al. 1991). If this is also the case in skeletal muscle, it may be that the lack of effects of $\mathrm{H}_{1}$ blockade on the blood pressure response to exercise reported in the previous study was due to offsetting effects of $\mathrm{H}_{1}$ blockade (i.e., reduced activation of afferents that cause reflex increases in blood pressure vs. increased vasoconstriction and TPR in the peripheral vasculature).

There are multiple possible sources for the production of histamine. It can be stored in and released from localized mast cells in most tissue (via degranulation) and from blood basophils (Hill, 1990). Complicating the situation is the fact that histamine can also be produced acutely (without being stored) by non-mast cells via the decarboxylation of histidine via histidine decarboxylase (Watanabe and Ohtsu, 2002). Due to these multiple pathways, it is presently not clear what mechanisms are responsible for the release of histamine during exercise. However, Halliwill et al. (2013) pointed out that factors associated with exercise, such as reactive oxygen species, cytokines and elevated body temperature, have been linked to mast cell degranulation.

\section{Limitations to the Study}

The primary limitation to the study was the fact that we did not measure regional blood flow, as it is very difficult to assess accurately and non-invasively in humans during dynamic exercise. Consequently, we were not able to determine the regional circulations affected by $\mathrm{H}_{2}$ receptor blockade that may have contributed to the concomitant increases in TPR 
Perspectives

Our findings may have potential clinical significance. For example, hypertensives often demonstrate an exaggerated blood pressure response to short term exercise (Colombo et al. 1989; Seguro et al. 1991). Interestingly, unlike normotensive subjects, they do not appear to demonstrate an increase in the release of histamine in response to short term exercise (Colombo et al. 1989). Thus, this ostensible inability to produce histamine may play a role, at least initially, in the corresponding augmentation of blood pressure in these individuals.

\section{Conclusions}

Results of this study demonstrate that histamine can act on $\mathrm{H}_{2}$ receptors to attenuate blood pressure, TPR and RPP in male subjects during short-term submaximal exercise that is capable of causing increases in plasma histamine. Since these effects occur in the absence of changes in HR, SV and CO, it appears that there is also a redistribution of $\mathrm{CO}$ whereby increases in blood flow in some regional circulations are offset by decreases in others. Consequently, we suggest that, during short term submaximal exercise, histamine mediates peripheral vasodilation that limits increases in blood pressure and afterload and lowers cardiac workload; effects that lessen stress on the heart.

\section{A conflict of interest}

This manuscript represents original research that has not been for publication elsewhere. All authors have no competing financial interests in relation to the work described, contributed substantially, and approved the final submission. 


\section{Acknowledgements}

We sincerely thank the subjects for volunteering to participate in this study. This work was supported by a grant from the Kyung Hee University (\#20100191). 


\section{References}

Black, J.W., Owen, D.A., and Parsons, M.E. 1975. An analysis of the depressor responses to histamine in the cat and dog: involvement of $\mathrm{H}_{1}$ and $\mathrm{H}_{2}$ receptors. Br. J. Pharmacol. 54: 319-324.

Brody, M.J. Neurohumoral mediation of reactive reflex dilitation. 1996. Fed. Proc. 25: 1583-1592.

Brown, N.J., and Roberts, L.J. Histamine, bradykinin, and their antagonists. 2001. In: Goodman and Gilman's The Pharmacological Basis of Therapeutics (10th ed.)., edited by Hardman J.G. and Limbird L.E. New York: McGraw Hill.

Campos, H.A., Montenegro, M., Velasco, M., Romero, E., Alvarez, R., and Urbina A. 1999. Treadmill exercise-induced stress causes a rise of blood histamine in normotensive but not in primary hypertensive humans Eur. J. Pharmacol. 383: 69-73.

Charloux, A., Lonsdorfer-Wolf, E., Richard, R., Lamper, E., Oswald-Mammosser, M, Mettauer, B., Geny, B., and Lonsdorfer, J. 2000. A new impedance cardiograph device for the non-invasive evaluation of cardiac output at rest and during exercise: comparison with the "direct" Fick method. Eur. J. Appl. Physiol. 82(4): 313-320.

Choi, H.M., Stebbins, C.L., Nho, H., Kim, M.S., Chang, M.J., and Kim, J.K. 2013. Effects of ovarian cycyle on hemodynamic responses during dynamic exercise in sedentary women. Korean $\mathrm{J}$. Physiol. Pharmacol. 17(6): 499-503.

Colombo, F., Porro, T., del Rosso, G., Bertalero, P., Orlandi, L., and Libretti, A. 1989. Cardiovascular responses to physical exercise and tyramine infusion in hypertensive and normotensive subjects. J. Hum. Hypertens. 3(4): 245-349.

Garg, D.C., Eshelman, F.N. and Weidler, D.J. 1985. Pharmacokinetics of ranitidine following oral administration with ascending doses and with multiple-fixed doses J. Clin. Pharmacol. 25(6): 437-443. 
Halliwill, J.R., Buck, T.H., Lacewell, A.N., and Romero, S.A. 2013. Postexercise hypotension and sustained postexercise vasodilatation: what happens after we exercise. Exp. Physiol. 98(1): 7-18, 2013.

Hill, S.J. 1990. Distribution, properties, and functional characteristics of three classes of histamine receptors Pharmacol. Rev. 42(1): 45-83.

Hughes, D.G., Dowling, E.A., DeMeersman, R.E., Garnett, W.R., and Karnes T. 1989. Cardiovascular effects of $\mathrm{H}_{2}$-receptor antagonists. J. Clin . Pharmacol. 29: 472-477.

Johnson, B.M., and Owe, D.A.A. 1977. Tissue blood flow and distribution of cardiac output in cats: Changes caused by intravenous infusions of histamine and histamine receptor agonists. Br. J. Pharmac. 60: 173-180.

Kaplan, V., Bucklar, G.B., and Bloch, K.E. 2003. Noninvasive monitoring of cardiac output during exercise by inductance cardiography. Med. Sci. Sports Exerc. 35(5): 747-75.

Kumazawa, T. and Mizumura, K. 1977. Thin-fibre receptors responding to mechanical, chemical and thermal stimulation in the skeletal muscle of the dog. J. Physiol. 273: 179-194.

Langer, S.Z., and Arbilla, S. Presynaptic receptors on peripheral norandrenergic neurons. 1990. Ann. N.Y. Acad. Sci. 604: 7-16.

Lockwood, J.M., Wilkins, B.W., and Halliwill, J.R. 2005. $\mathrm{H}_{1}$ receptor-mediated vasodilatation contributes to postexercise hypotension J. Physiol. 563(2): 633-642.

Malinowska, B., Godlewski, G., and Schlicker, E. 1998. Histamine $\mathrm{H}_{3}$ receptors-general characterization and their function in the crdiovascular system. J. Physiol. Pharmacol. 49(2): 191-21.

McCord, J.L., Beasley, J.M. and Halliwill, J.R. 2006. $\mathrm{H}_{2}$-receptor-mediated vasodilation contributes to postexercise hypotension. J. Appl. Physiol. 100: 67-75.

McGrath, M.A., and Shepherd, J.T. 1978. Histamine and 5-hydroxytryptamine-inhibition on transmitter release mediated by $\mathrm{H}_{2}$ - and 5-hydroxytryptamine receptors. Fed. Proc. 37(2): 195-198. 
Mitchell, J.H., Kaufman, M.P., and Iwamoto, G.A. 1983. The exercise pressor reflex: Its cardiovascular effects, afferent mechanisms, and central pathways. Ann. Rev. Physiol. 45: 229-242.

Nault, M.A., Bilne, B., and Parlow, J.L. 2001. Effects of selective $\mathrm{H}_{1}$ and $\mathrm{H}_{2}$ histamine reeptor antagonists loaratadine and ranitidine on autonomic control of the heart rate. Anesthesiology 96: 336-341.

Peterlin, M.F., Keyser, R.E., Andres, F.F., and Sherman, G. 1998. Nonprescription chlorpheniramine maleate and submaximal exercise responses. Arch. Phys. Med. Rehabil. 79: 827-831.

Powell, J.R., and Brody, M.J. 1976. Participation of $\mathrm{H}_{1}$ and $\mathrm{H}_{2}$ histamine receptors in physiological vasldilatior responses. Am. J. Physiol. 231(4): 1002-1009.

Rengo, F., Trimarco, B., and Chiariello, M., Sacca, L., Violini, R., Resetti, G., and Ferro, G. 1978. Relation between cholinergic and histaminergic components in reflex vasodilitation in the dog. Am. J. Physiol. Heart Circ. Physiol. 234(3): H305-H311.

Richard, R., Lonsdorfer-Wolf, E., Charloux, A., Doutreleau, S., Buchheit, M., Oswald-Mammosser, M., Lampert, E., Mettauer, B., Geny, B., and Lonsdorfer, J. 2001. Non-invasive cardiac output evaluation during a maximal progressive exercise test, using a new impedance cardiograph device. Eur. J. Appl. Physiol . 85(3-4): 202-207.

Saltissi, S., Crowther, A., Byrne, C., and Coltart, D.J. 1981. The effects of chronic oral cimetidine therapy on the cardiovascular system in man. Br. J. Clin. Pharmac. 11: 497-503.

Schrage, W.G., Joyner, M.J., and Dinenno, F.A. 2004. Local inhibition of nitric oxide and prostaglandins independently reduces forarm exercise hyperaemia in humans. J. Physiol. 557(2): 599-611.

Seguro, C., Sau, F., Zedda, N., Scano, G., and Cherch, I.A. 1991. Arterial blood pressure behavior during progressive muscular exercise in subjects with stable arterial hypertension. Cardiologia 36(11): 867-877.

Shepherd, J.T., and Vanhouttee, P.M. 1985. Local modulation of adrenergic neurotransmission in blood vessels. J. Cardiovasc. Pharmacol. 7 Supp1 3: 167-178. 
Skidgel, R.A., Kaplan, A.P. and Erdos, E.G. 2012. Histamine, bradykinin and their antagonists. In Goodman and Gilman's the Pharmacological Basis of Therapeutics. $12^{\text {th }}$ edition. Edited by L.L. Brunton, B.A. Chabner and B.C. Krollman, McGraw-Hill, New York, N.Y., USA. pp 911-936.

Stebbins, C.L., Theodossy, S.J. and Longhurst, J.C. 1991. Cardiovascular reflexes evoked by histamine stimulation of the stomach. Am. J. Physiol. 260(4): H1098-H1 105.

Tordi, N., Mourot, L., Matushesk, I..B., and Hughson, R.L. 2004. Measurements of cardiac output during constant exercises: comparison of two non-invasive techniques. Int. J. Sports Med. 25(2): 145149.

Watanabe, T., and Ohtsu, H. 2002. L-histindine decarboxylase as a probe in studies of histamine. Chem. Rec. 2(6): 369-376.

Watkins, J., Dargie, H.j., Brown, M.J., Krikler, D.M., and Dollery, C.T. 1982. Effects of histamine type 2 receptor stimulation on myocardial function in normal subjects. Br. Heart J. 47: 539-545. 
Table 1. Physical characteristics of subjects.

\begin{tabular}{lc}
\hline Variables & $(\mathrm{n}=14)$ \\
\hline Age $(\mathrm{yrs})$ & $21 \pm 0.1$ \\
Height $(\mathrm{cm})$ & $64.9 \pm 1.4$ \\
Body weight $(\mathrm{kg})$ & $21.1 \pm 0.3$ \\
BMI $\left(\mathrm{kg} / \mathrm{m}^{2}\right)$ & $111 \pm 2$ \\
SBP $(\mathrm{mmHg})$ & $73 \pm 1$ \\
DBP (mmHg) & $86 \pm 1$ \\
MAP (mmHg) & $75 \pm 3$ \\
Resting HR (beats/min) & $45.2 \pm 1.9$ \\
VO ${ }_{2}$ peak (ml/kg/min) & \\
\hline Values are expressed as mean \pm standard error. BMI, body mass index; SBP, systolic blood pressure; DBP, \\
diastolic blood pressure; MAP, mean arterial pressure; HR, heart rate; VO 2 peak, volume of oxygen \\
uptake.
\end{tabular}




\section{Figure Legends}

Figure 1 SBP, DBP, MAP and HR at rest and during exercise before (Control, CON) and during Histamine $\mathrm{H}_{2}$ receptor blockade (BLK). Vertical brackets reflect a significant effect of blockade and horizontal brackets reflect a significant effect of exercise $(P<0.05) . * P<0.05$ vs. CON; ${ }^{\#} P<0.05$ vs. rest.

Figure 2 CO, SV, TPR and RPP at rest and during exercise before (Control, CON) and during histamine $\mathrm{H}_{2}$ receptor blockade (BLK). Vertical brackets reflect a significant effect of blockade and horizontal brackets reflect a significant effect of exercise $(P<0.05)$. ${ }^{*} P<0.05$ vs. CON; ${ }^{\#} P<$ 0.05 vs. rest.

Figure 3 Plasma concentrations of $\mathrm{NE}$ at rest and during exercise before (Control, CON) and after histamine $\mathrm{H}_{2}$ receptor blockade (BLK). Horizontal brackets reflect a significant effect of blockade $(P<0.05)$. 

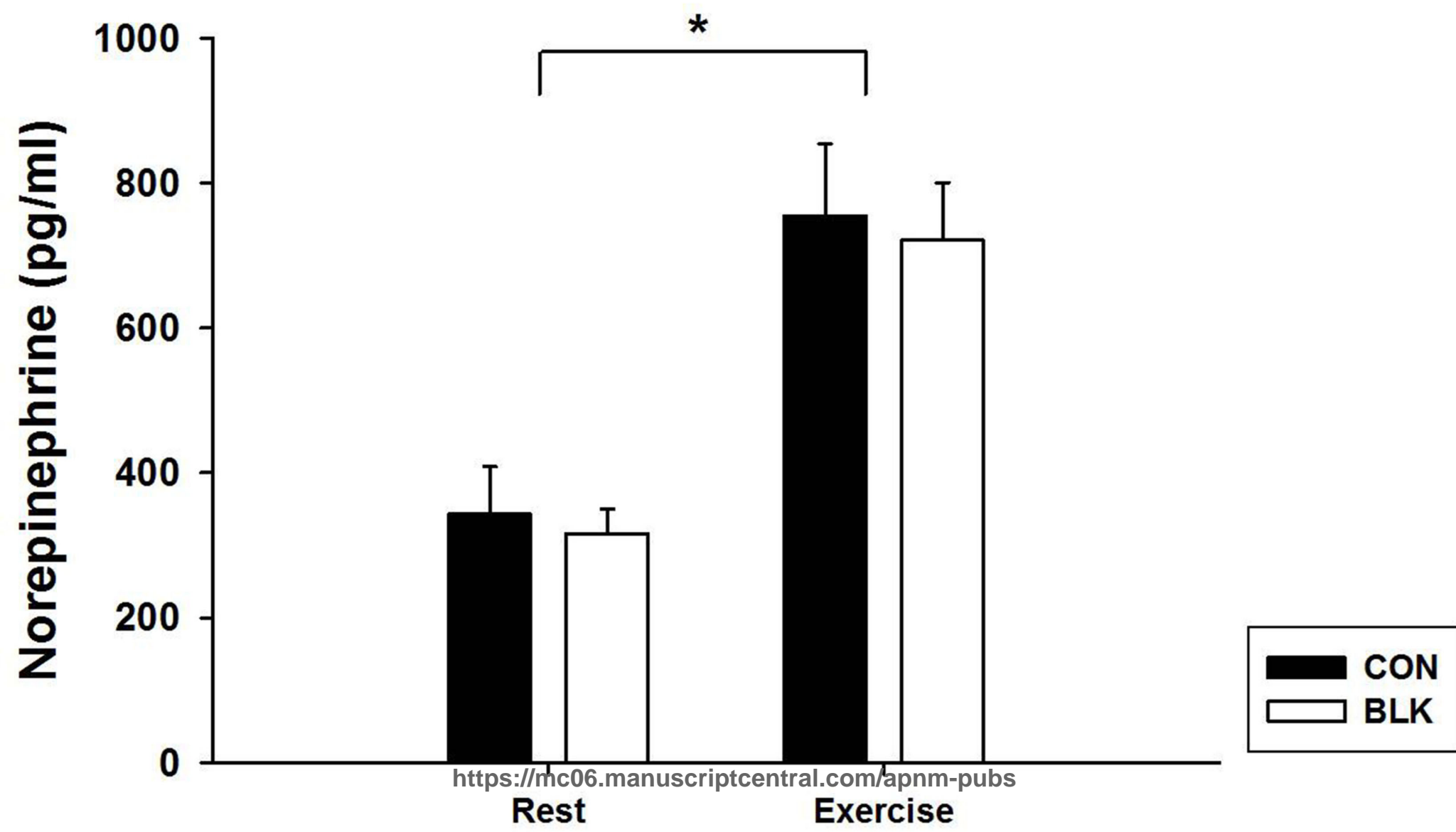